\title{
CJEU ACHMEA JUDGMENT AND WHAT COMES NEXT. SOME REFLECTIONS ON THE POTENTIAL IMPLICATIONS OF THE CJEU JUDGMENT OF 6.3.2018 (C-284/16) ${ }^{1}$
}

The Times They Are a-Changin' Bob Dylan

Abstract: In the judgment of 6.03.2018 (Achmea case, C-284/16), CJEU ruled that treaty clauses that allow investor from one of the Member States to bring proceedings against another Member State before an arbitral tribunal outside the EU judicial system are irreconcilable with Articles 267 and 344 TFEU when such tribunal may be called on to interpret or apply EU law. This principle is applicable to EU trade or investment agreements (FTAs and IIAs), since they are part of EU law, and to BITs, FTAs and IIAs, since they contain explicit or implicit referrals to municipal (EU) law. In intra-EU relations, such a conflict of norms must be solved according to customary international law codified in the VCLT. According to this law, TFEU would prevail as lex superior and, in the case of Poland and many other Member States, as lex posterior. In intra-EU relations, TFEU

* Ph.D., participant of a research seminar in international and European law at the Cardinal Stefan Wyszyński University in Warsaw. The paper reflects the author's personal views, which are not necessarily shared by any institution he is associated with.

1 Hereinafter: Achmea judgment. 
prevails ex proprio vigore, i.e. without the need to terminate intra-EU BITs. However, such termination is highly desirable, not only for reasons of clarity, but also because arbitral tribunals and extra-EU courts are not bounded by the ECJ's ruling. In the case of agreements with non-Member States, the incompatibilities referred to in the Achmea judgment must be eliminated by renegotiation or formal termination (Article 307 (2) TFEU). In the case of the BITs, the latter seems to be the only practical solution.

Keywords: ISDS, ICS, MIC, BIT, IIA, FTA, TIPs, intra-EU BIT, CETA, Achmea, international investment arbitration, international arbitral tribunals

\section{The facts of the Achmea case}

On 6.3.2018, CJEU rendered a precedential judgment on inconsistency of international arbitration as a mode of investor-State dispute settlement (ISDS) ${ }^{2}$ with EU law. The facts of the case can be summarised as follows: In 2004, Slovakia opened its market to private operators. One of those, a Dutch company-Achmea (at the time operating under the name "Eureko"), offered private sickness insurance services on the Slovak market. In 2006, Slovakia partly reversed the opening. Achmea considered that such a reversal had caused it damage and brought arbitration proceedings against Slovakia, pursuant to Article 8 of the NL-SK BIT ${ }^{3}$. In those arbitration and postarbitration proceedings, Slovakia raised an objection of lack of jurisdiction of the arbitral tribunal. It submitted in that respect that, as a result of its accession to the European Union, recourse to an arbitral tribunal provided for in Article 8 (2) of the BIT was incompatible with EU law ${ }^{4}$.

2 ISDS is to be distinguished from commercial arbitration (Achmea judgment, para. 55 and the case law cited).

3 Agreement on encouragement and reciprocal protection of investments between the Kingdom of the Netherlands and the Czech and Slovak Federative Republic.

4 Achmea judgment, para. 6-11. 


\section{Legal reasoning of the CJEU}

The CJEU requested for a preliminary ruling in the post-arbitration proceedings, which ruled that consistency of the arbitration clause with EU law depends on whether the disputes which the arbitral tribunal mentioned in the BIT is called on to resolve are liable to relate to the interpretation or application of $\mathrm{EU} \mathrm{law}^{5}$, particularly the provisions concerning the fundamental freedoms, including freedom of establishment and free movement of capital. In order to rule on possible infringements of the BIT, the arbitral tribunal must take account in particular the law in force of the contracting party concerned and other relevant agreements between the contracting parties. Therefore, to ensure consistency of the arbitration clause with the BIT, such an arbitral tribunal would have to be situated within the EU judicial system (its decisions would have to be subjected to mechanisms capable of ensuring the full effectiveness of EU law). This it is not the case of BIT arbitration. Indeed, it is precisely the exceptional nature of the arbitral tribunal's jurisdiction compared with that of the Member States' courts, which is one of the principal reasons for the existence of the BIT ${ }^{6}$.

CJEU ruled that regulations such as Article 8 of the NL-SK BIT, under which an investor from one of these Member States may, in the event of a dispute concerning investments in the other Member State, bring proceedings against the latter Member State before an arbitral tribunal whose jurisdiction that Member State has undertaken to accept, are irreconcilable with Articles 267 and 344 TFEU. The phrase "such as Article 8 of the NL-SK BIT" should be interpreted in the light of para. 42 of the judgment as a reference to "a tribunal that may be called on to interpret or indeed to apply EU law, particularly the provisions concerning the fundamental freedoms, including freedom of establishment and free movement of capital".

5 EU law must be regarded both as forming part of the law in force in every Member State and as deriving from an international agreement between the Member States.

6 Achmea judgment, para. 39-46. 


\section{Scope of application of the judgment}

In order to assess the scope of application of the principle pronounced in the Achmea judgment, it must be investigated as to when an arbitral tribunal may be called upon (it is worth noting the phrase used is "may" instead of "shall") to interpret or apply EU law.

First - the international agreements referred to in Article 216 TFUE, such as EU free trade or investment agreements (FTAs and IIAs), are part of EU law. Substantive provisions of such agreements concluded by the EU (with the exception of the provisions relating to non-direct foreign investment and those relating to dispute settlement between investors and States) fall within the exclusive competence of the EU?

Second - all treaties (BITs and EU FTAs and IIAs) contain explicit ${ }^{8}$ or implicit references to municipal law ${ }^{9}$, in particular in the FET, expropriation and umbrella clauses. All treaties oblige States to treat investors in a "fair and equitable" way (FET clause). According to arbitral practice, if a measure adopted by the host State towards an investor grossly ${ }^{10}$ violates national law, it violates the FET clause. Apart from the FET clauses, all the treaties protect investors against expropriation (including indirect or creeping expropriation) and provide that if such expropriation is to be in conformity with the treaty, it must be concluded inter alia in accordance with the national

7 CJEU opinion 2/15 of 16.5.2017 pursuant to Article 218 (11) TFEU on the Free Trade Agreement between the European Union and the Republic of Singapore, ECLI:EU:C:2017:376.

8 E.g. in the Treaty between the United States of America and the Republic of Poland Concerning Business and Economic Relations: Article III (1) "Subject to the laws in force within their territories, the Parties agree to allow the import and re-export on a dutyfree basis of all articles for use in trade promotion events, provided that such articles are not sold or otherwise transferred"; Article V (3) "either Party may protect the rights of creditors, or ensure the satisfaction of judgments in adjudicatory proceedings, through the equitable, nondiscriminatory and good faith application of its law".

9 A.P. Newcombe, L. Paradell, Law and Practice of Investment Treaties: Standards of Treatment, Alphen aan den Rijn 2009, pp. 92-96.

10 "Manifest injustice", "manifest violation of law or of manifest bad faith application of law or in weighing the evidence filed by the parties", "manifestly unjust and partial decision", "clear and malicious misapplication of the law", "blatant disregard of rights created under national law" (J. Paulson, Denial of Justice in International Law, Cambridge University Press, Cambridge 2005, p. 73-81). See also: M. Menkes, Governance gospodarczy - studium prawno międzynarodowe [Economic governance: a study from the international law perspective], Warsaw 2016, pp. 296-297. 
law ${ }^{11}$. Treaties provide for different standards of compensation in the case of lawful and unlawful expropriation ${ }^{12}$. If a treaty contains an "umbrella clause" that creates a treaty obligation that a host State shall observe any obligation or commitment it has assumed in respect to the investment, such a clause extends arbitral jurisdiction beyond the mere violation of the treaty to violation of the investment contract ${ }^{13}$. In order to decide whether the host State has violated a contract, the arbitral tribunal must interpret or apply the national law as lex loci contractus.

Against this background, it must be concluded that the irreconcilability referred to in the Achmea judgment refers to the arbitration envisaged in: (1) all BITs concluded by the Member States, both intra- and extra-EU, and to (2) all EU FTAs and IIAs ${ }^{14}$.

\section{Conflict of norms in public international law}

The Achmea judgment is silent on the practical consequences of inclusion to BITs IIAs or FTAs clauses precluded by Articles 267 and 344 TFEU. Such consequences are specified by the customary international law, in this aspect codified in the Vienna Convention on the Law of the Treaties (hereinafter VCLT) ${ }^{15}$. The relevant Article 30 of the VCLT is worded as follows:

11 Ł. Kułaga, Traktowanie sprawiedliwe i stuszne a minimalny standard traktowania $w$ międzynarodowym prawie inwestycyjnym [Fair and Equitable Treatment and minimum standards of treatment in international investment law], Wydawnictwo UKSW, Warsaw 2016, pp. 117-118.

12 M. Kantor, Valuation for Arbitration: Compensation Standards, Valuation Methods and Expert Evidence, Alphen aan den Rijn, 2008, pp. 66.

$13 \mathrm{~K}$. Yannaca-Small, Interpretation of the Umbrella Clause in Investment Agreements, OECD Working Papers on International Investment 2006/03, OECD Publishing.

14 All doubts should be clarified in the forthcoming CJEU opinion 1/17 pursuant to Article 218 (11) TFEU on the compatibility of the new Investor Court System (ICS) in CETA with the EU law.

15 K. Schmalenbach [in:] O. Dörr, K. Schmalenbach (ed.), "Vienna Convention on the Law of Treaties. A Commentary", Berlin 2018, p. 29. Rules such as lex superior derogat legi inferiori, lex posterior derogat legi priori, lex specialis derogat legi generali are long established general principles of law (H-G. Dederer, D. Wüger, and Th. Cottier, Genetic Engineering and the World Trade System [in:] Ch. Herrmann, J. P. Terhechte (ed.) "European Yearbook of International Economic Law" 2011, Berlin 2011, p. 453, p. 465). 
Article 30 Application of successive treaties relating to the same subject-matter

1. Subject to Article 103 of the Charter of the United Nations, the rights and obligations of States parties to successive treaties relating to the same subject-matter shall be determined in accordance with the following paragraphs.

2. When a treaty specifies that it is subject to, or that it is not to be considered as incompatible with, an earlier or later treaty, the provisions of that other treaty prevail.

3. When all the parties to the earlier treaty are parties also to the later treaty but the earlier treaty is not terminated or suspended in operation under article 59, the earlier treaty applies only to the extent that its provisions are compatible with those of the latter treaty.

4. When the parties to the later treaty do not include all the parties to the earlier one:

- as between States parties to both treaties the same rule applies as in paragraph 3;

- as between a State party to both treaties and a State party to only one of the treaties, the treaty to which both States are parties governs their mutual rights and obligations.

5. Paragraph 4 is without prejudice to article 41 , or to any question of the termination or suspension of the operation of a treaty under article 60 or to any question of responsibility which may arise for a State from the conclusion or application of a treaty, the provisions of which are incompatible with its obligations towards another State under another treaty.

Articles 267 and 344 TFUE, on one hand, and the arbitration clause, on the other, refer to the same matter: arbitration. They are incompatible with each other since the former precludes any arbitration provided for by the latter. Therefore, a conflict of norms exists ${ }^{16}$.

16 A conflict of norm exists "when a rule in one agreement prohibits what a rule in another agreement explicitly permits" (European Communities - Regime for the Importation, Sale and Distribution of Bananas, WTO panel report of 25.9.1997, WT/DS27/R, para. 7.159). On the definitions of conflict of norms, see also: Fragmentation of International Law. Report of the Study Group of the International Law Commission Finalized by Martti Koskenniemi, 13.4.2006, A/CN.4/L.682, para. 21-23, and J. Pauwelyn, Conflict of Norms in Public International Law, Cambridge 2003, p. 170. 


\section{TFEU as lex superior to intra-EU BIT}

In the event of such a conflict (the obligations of the Member States under the TFEU vis-à-vis their rights and obligations under intra-EU BITs), the obligations under the TFEU prevail. Although TFEU does not contain an explicit supremacy clause comparable to Article 103 of the UN Charter or Article 311 of the United Nations Convention on the Law of the Sea, according to the UN International Law Commission, the TFEU takes absolute precedence over agreements that Member States have concluded between each other ${ }^{17}$. This is so because the priority clause might be only implicit ${ }^{18}$. The implicit priority clause of the TFEU can be derived from its special position in the EU legal framework. As the CJEU has repeatedly held, European treaties established a new legal order, possessing its own institutions, for the benefit of which the Member States thereof have limited their sovereign rights, in ever wider fields, and the subjects of which comprise not only those States but also their nationals ${ }^{19}$. This means that the EU has a new kind of autonomous legal order with its own constitutional framework ${ }^{20}$. Therefore, all international agreements concluded between Member States must be in conformity with the basic constitutional charterthe European treaties - and may not affect the specific characteristics of the EU and EU law ${ }^{21}$.

In addition, the principle of sincere cooperation set out in Article 4 (3) TEU obliges Member States to ensure, in their respective territories, the application of and respect for EU law. Therefore, Member States (in practice: their organs including the judicial authorities ruling on a petition

17 Fragmentation of International Law. Report of the Study Group of the International Law Commission Finalized by Martti Koskenniemi, 13.4.2006, A/CN.4/L.682, para. 283.

18 R. Kolb, The Law of Treaties: An Introduction, Edward Elgar, Cheltencham 2016, p. 188. For greater clarity, parties to the conflicting treaties may stipulate the subordination or primacy by virtue of an interpretative note (See e.g. General interpretative note to Annex 1A of the WTO Agreement: "In the event of conflict between a provision of the General Agreement on Tariffs and Trade 1994 and a provision of another agreement in Annex $1 \mathrm{~A}$ to the Agreement Establishing the World Trade Organization, the provision of the other agreement shall prevail to the extent of the conflict").

19 Van Gend \& Loos, CJEU judgment of 5.2.1963, C- 26/62, para. 3, and Costa, CJEU judgment of 15.7.1964, C-6/64, p. 593.

${ }^{20}$ CJEU opinion 2/13 of 18.12.2014 on the accession of the EU to the ECHR, EU:C:2014:2454 2/13, para. 158.

${ }^{21}$ Ibid., para. 174. 
for reversal of an arbitral award) are to take any appropriate measure, general or particular, to ensure fulfilment of the obligations arising out of European treaties ${ }^{22}$.

\section{TFEU as lex posterior to intra-EU BIT}

In the particular case of Poland, an additional way of solving this normative conflict is available. According to the universally recognised lex posterior rule, if a party of the intra-EU BIT became party of European treaties after conclusion of the BIT, the BIT, as the earlier treaty, applies only to the extent that its provisions are compatible with those of the latter treaty ${ }^{23}$. It is worth noting that at the time of the Achmea arbitral proceedings, Poland shared this view ${ }^{24}$.

\section{Practical consequences}

According to the lex superior rule, TFEU "prevails" 25 over intra-EU BITs. According to the lex posterior rule, the arbitration clause of the BIT cannot be "applied". Neither the VCLT nor State practice rooted in the customary international law suggest that by virtue of those rules earlier inferior treaties (scil.: arbitration clauses) were terminated or became invalid or void ${ }^{26}$. The validity of a norm must be strictly separated from its

22 CJEU opinion 1/09 of 8.3.2011 on agreement creating a unified patent litigation system, EU:C:2011:123, para. 172.

23 Article 30 (3) of the VCLT. See also position of the European Commission in the Achmea arbitration proceedings (Eureko B. V. v. the Slovak Republic, E-SR Award on Jurisdiction, etc. of 26.10.2010, PCA Case No. 2008-13 (hereinafter: Achmea award), para. 188-192.

24 In response to an e-mail from Slovakia with an invitation to terminate intra-EU BIT, Poland replied that "from the day of accession, articles which are not compatible with the EU acquis communautaire according to Article 59 in connection with Article 30 par. 3 of Vienna Convention are terminated (lex posterior derogate lex priori). Therefore, there is no need to initiate any procedure" (Achmea award, para. 91).

25 Wording taken from Article 30(2) VCLT that directly deals with an issue of the subordination clause (not priority clause), but as to the effect, both should be considered to be analogous.

${ }^{26}$ Comp. Articles 53, 64, 69 VCLT. 
applicability in a given case. Therefore, even though intra-EU BITs in totality (or their arbitration clauses) have not been implicitly terminated or nullified by virtue of lex superior or lex specialis rules, EU law prevails, and arbitration clauses cannot be applied, which means that arbitral tribunals cannot exercise their jurisdiction. This was also the position taken by the arbitral tribunals ${ }^{27}$ (including, at least in principle, the tribunal that issued the Achmea award ${ }^{28}$. CJEU shares this view, as it repeatedly held, "the provisions of a convention between two Member States cannot apply in the relations between those States if they are found to be contrary to the rules of the TFEU"29.

\section{Termination of BITs}

Poland's position towards intra-EU BITs was adopted by the government's Committee of European Affairs on 3.6.2011. It states that all intra-EU BITs should be terminated by all the Member States in a coordinated way, preferably by a common note based on the VCLT confirming the cessation of applicability of intra-EU BITs ${ }^{30}$. If the agreement of the Member State could not been reached, Poland, according to the above mentioned position, should terminate intra-EU BITs either by denunciation or by joint declaration (in the case of those States that would be willing to agree

27 E.g. Electrabel S. A. v. Hungary, Award on Jurisdiction of 30.11.2012, ICSID Case No. ARB/07/19, para. 4.190-4.191.

28 According to para. 272-274 of the Achmea award, if Article 8 of the applicable BIT, which provides for arbitration, was by itself incompatible with EU law, Article 30 (3) of the VCLT would, at least arguably, deprive the Tribunal of jurisdiction. The award (in contradiction to the position taken later by the CJEU in the Achmea judgment) held that the claim is admissible because "there is no rule of EU law that prohibits investorState arbitration", but the position that the arbitral tribunal took on the other point of law - the applicability of Article 30 VCLT - was correct.

${ }^{29}$ Achmea judgment, para. 47; Ravil, CJEU judgment of 20.4.2003, C-469/00, para. 37, and Exportur, CJEU judgment of 10.11.1992, C-3/91, para. 8.

30 This is also the position of the European Commission (A. Różalska-Kucal, Intra-EU BITs - are They Really Still Necessary? The Best Award of the Year 2012 and Professor Emmanuel Gaillard Say "Yes", "Polish Review of International and European Law" 2012, vol. 11, no. 3-4, p. 27, p. 29). 
to such a form of termination) $)^{31}$. The Achmea judgment should not change this position. Even though it refers only to one provision of the BITs (arbitration clause) and shows that even without any further action from Member States arbitration is inadmissible, it provides a strong argument for fast termination of intra-EU BITs, first and foremost, in the name of legal certainty ${ }^{32}$.

As long as BITs are formally in force, there is a risk that arbitral tribunals could defy the existence of a conflict between BIT and EU law ${ }^{33}$ or, even if they would acknowledge the existence of such a conflict, they would solve it in favour of an investor ${ }^{34}$. This position, although erroneous, ${ }^{35}$ would not be manifestly arbitrary since the Achmea judgment is not legally (ratione imperii) binding to the arbitral tribunals, and it might not be binding imperatio rationis, not only because in the current system there are some incentives ${ }^{36}$ that might be seen as pushing arbiters to rule in favour of jurisdiction, but also because the position against the existence of a conflict of norms was taken by the Advocate General in the Achmea case. This allows arbiters to rule in dubio pro iudici activitatem without losing

31 Draft Act on termination of the agreement on the promotion and reciprocal protection of investments, signed between Poland and Portugal on 11.3.1993 (Sejm file (VIII term) no. 1775, p. 3).

32 Commission v. France, CJEU judgment of 4.4.1974, C-167/73, para. 46-47.

33 See opinion of the CJEU Advocate General M. Wathelet delivered on 19.9.2017 in the Achmea case (ECLI:EU:C:2017:699).

34 For example, by pointing out that once investor has been granted some (substantive or procedural) rights, he cannot be deprived of them without his consent (Article 36(1)) VCLT per analogiam. On the discussion on applicability of Article 36(1) VCLT to nonState actors, see: A. Proless [in:] O. Dörr, K. Schmalenbach (ed.) "Vienna Convention on the Law of Treaties. A Commentary”, Berlin 2018, p. 717 and pp. 661-663..

35 Not only because investors are only agents of States and are permitted for convenience to enforce what are in origin the rights of State Parties (Loewen Group, Inc. and Raymond L. Loewen v. United States, arbitral award of 26.7.2003, ICSID Case No. $A R B(A F) / 98 / 3$, para. 233), but primary because any international treaty can be terminated, suspended, modified or made inapplicable by consent of the parties expressed, e.g. in the posterior treaty. Such is the fundamental principle of international law applicable even in the case of human rights treaties (E. Bates, Avoiding Legal Obligations Created by Human Rights Treaties, "International and Comparative Law Quarterly" 2008, vol. 57, no. 4, p. 751, p. 755). More on the "agency theory" and also on other competing theories on the nature of BITs and rights derived from them, see in: Ł. Kułaga, Ochrona praw człowieka w międzynarodowym arbitrażu inwestycyjnym [Protection of Human Rights in Investment Arbitration], "Forum Prawnicze" 2014, no. 1 (21), p. 41, pp. 43-46.

36 The arbitrators are paid hourly. 
professional credibility. Only formal termination of the intra-EU BITs would guarantee that they would not be applied in practice. The possible annulment of an arbitral award by a common court is not enough, since only the courts of the Member States are legally bound by CJEU judgments (acte éclairé $)^{37}$. Therefore, in the case of petition for annulment filed to a nonMember State court (this might be the case if the arbitral tribunal was seated outside the EU), the outcome of such proceedings is uncertain. Furthermore, even successful annulment of the arbitral award might not stop it from being enforced if the enforcing authorities conclude that because of its international nature, it is not attached to any municipal legal order ${ }^{38}$ and thus continues to exist despite its annulment at the seat of arbitration ${ }^{39}$. Last but not least, termination of BITs is desirable not only for legal reasons, but also for socio-economic reasons, as a policy choice ${ }^{40}$. Without prejudice to other obligations arising from EU law (in particular, transfer clauses of the extra-EU BITs ${ }^{41}$ ), BITs, if denounced, would be disposed of in effect only after completion of the sunset clauses. Therefore, denunciation is the least favourable way of their termination. Termination by mutual consent is much more desirable. It should be expected that the European Commission would assist States (such as Poland)

37 S. Douglas-Scott, Constitutional Law of the European Union, Pearson Education, Harlow 2002, pp. 244-245.

38 C. Alfons, Recognition and Enforcement of Annulled Foreign Arbitral Awards, Peter Lang, Frankfurt am Main 2010, pp. 144-145.

39 In jurisprudence, see notably: Société Hilmarton Ltd v. Société Omnium de traitement et de valorisation (OTV), French Cassation Court judgment of 23.3.1994, Case No. 92-15.137; Yukos Capital SARL v. OJSC Rosneft Oil Company, English High Court of Justice judgment of 3.7.2017, [2014] EWHC 2188 (Comm), and in a more nuanced way: Yukos Capital S.A.R.L.v. OAO Rosneft, judgment of Amsterdam Court of Appeal of 28.4.2009, Case No. 200.005.269/01. More on this subject: Ch. Pamboukis, The Annuled Arbitral Award. Jurisdictio Facit Arbitrum, "Yearbook of Private International Law" 2015/2016, vol XVII, p. 83.

40 On the criticism of the current ISDS system, see: Ł. Kułaga, Międzynarodowy arbitraż inwestycyjny z perspektywy zasady rząów prawa [International investment arbitration from the perspective of the rule of law pricinple], [in:] C. Mik (ed.), "Arbitraż w prawie międzynarodowym" [Arbitration in international law], Warsaw 2014, p. 202, pp. 209-212.

41 P. Rogulski, Rozwiq̨zywanie sporów inwestycyjnych-doświadczenia polskie [Resolution of investment disputes - Polish experiences], [in:] B. Kuźniak (ed.), "Sądy i trybunały oraz pozasądowe sposoby załatwiania sporów międzynarodowych. Perspektywa polska” [Courts and tribunals and alternative dispute resolution in the area of international law. Polish perspective], Warsaw 2015, p. 165, pp. 172-173. 
that wish to terminate their BITs consensually. Continuing the EU-Pilot ${ }^{42}$ procedure against Member States that refuse such an offer is therefore highly desirable, if not implicitly required, by the Achmea judgment.

\section{EU FTAs, IIAs and MIC}

EU agreements such as CETA and other agreements establishing ISDS or ICS would be part of UE law ${ }^{43}$. Pursuant to Articles 216 and 218 TFEU, such agreements must remain in conformity with the European Treaties ${ }^{44}$; therefore, the adjudicating body they establish must be part of the EU judicial system. Its decisions must be subjected to mechanisms capable of ensuring the full effectiveness of the rules of EU law ${ }^{45}$. This principle would have to be observed in the process of drafting a convention establishing a Multilateral Investment Court ${ }^{46}$. If integrating such an adjudicating body with the EU judicial system would be unacceptable for the non-EU States, ISDS/ICS would have to be replaced with an alternative system of investor protection. In this context, contemporary investment treaties

42 EU Pilot is an informal dialogue between the Commission and the Member State concerned with issues related to potential non-compliance with EU law, prior to launching a formal infringement procedure under Article 258 TFEU. By Letters of Formal Notice sent within the framework of the EU-Pilot procedure, the European Commission requested Member States to bring the intra-EU BITs between them to an end ( $€$. Kułaga, Unia Europejska a zmiana paradygmatu w międzynarodowym prawie inwestycyjnym [The European Union and the change of paradigms in international investment law], "Europejski Przegląd Sądowy" 2017, no. 4 (139), p. 4, p. 5).

43 Article 216(2) TFEU. In literature see: C. Mik, Europejskie prawo wspólnotowe. Zagadnienia teorii i praktyki. Tom 1 [European community law. Theoretical and practical aspects], Warsaw 2000, p. 507; R. \& V. Haegeman v. Belgian State, CJEU judgment of 30.4.1974, C-181/73, para. 3-5 and Demirel v. Stadt Schwäbisch Gmünd, CJEU judgment of 30.9.1987, C-12/86, para. 6-12.

44 A. Wróbel, Stosowanie prawa Unii Europejskiej przez sq̨dy. Tom I [The Application of the EU law by courts], Warsaw 2010, p. 75.

45 Achmea judgment, para. 43.

46 Works under the auspices of UNCITRAL have already begun: http://www. uncitral.org/uncitral/en/commission/working_groups/3Investor_State.html (accessed 10.04.2018). On the mandate to the Commission to open negotiations, see: http://www. consilium.europa.eu/en/press/press-releases/2018/03/20/multilateral-investmentcourt-council-gives-mandate-to-the-commission-to-open-negotiations/ (accessed 10.4.2018). 
provide for administrative protection based on a system of contact points or ombudsman ${ }^{47}$. Mediation is another interesting alternative form of investment dispute resolution ${ }^{48}$. Traditional methods of protection, such as recourse to international human rights institutions or diplomatic protection, are also available. Investors may also purchase political risk insurance ${ }^{49}$.

\section{Extra-EU BIT}

According to Article 351 TFEU, the rights and obligations arising from agreements concluded by the Member State and third countries before accession to the EU, between one or more Member State on the one hand and one or more third countries on the other hand, shall not be affected by the European Treaties. However, to the extent that such agreements are not compatible with the Treaties, the Member State shall take all appropriate steps to eliminate the incompatibilities established. Member States shall, where necessary, assist each other to this end and shall, where appropriate, adopt a common attitude ${ }^{50}$. In the case of extra-EU BIT, this principle is reaffirmed by Recital 11 of the preamble to Regulation (EU) No. 1219/2012 of the European Parliament and of the Council of 12 December 2012 establishing transitional arrangements for bilateral investment agreements between Member States and third countries ${ }^{51}$.

According to the Achmea judgment, when the dispute which the arbitral tribunal is called on to resolve is liable to relate to the interpretation or application of EU law, including the provisions concerning the fundamental freedoms, such as freedom of establishment and free movement of capital, the tribunal must be situated within the judicial system of the EU.

47 Ł. Kułaga, W kierunku zmiany paradygmatu międzynarodowych porozumień inwestycyjnych [Towards the change of paradigms of international investment treaties], "Forum Prawnicze" 2016, no. 5 (37), p. 44.

48 N. Welsh, A. Schneider, The Thoughtful Integration of Mediation into Bilateral Investment Treaty Arbitration, "Harvard Negotiation Law Review" 2013, vol. 18, p. 71, pp. 105-133.

49 D. Wagner, Managing Country Risk: A Practitioner's Guide to Effective Cross-Border Risk Analysis, New York 2012, p. 257.

50 This is one of the aspects of a duty of sincere cooperation set out by Article 4 (3) TEU (M. Klamert, The Principle of Loyalty in EU Law, Oxford 2014, p. 14).

51 OJ L 351, 20.12.2012, pp. 40-46. 
It is uncontested that arbitral tribunals established by the extra-EU BITs fall outside of this system. This imposes a legal duty on Member States to eliminate the conflict between extra-EU BITs and EU Law by either (1) renegotiating extra-EU BIT in order to place arbitral tribunals within the EU judicial system, or (2) terminating extra-EU BITs. Acquiring the partner's consent to renegotiate BITs does not seem likely (the fundamental rationale of arbitration is to put dispute a settlement mechanism independent from the municipal judicial systems). Therefore, the only realistic option is the termination of extra-EU BITs, regardless of when, why and with which country they have been concluded. Consequently, all ongoing BIT negotiations ${ }^{52}$ must take the Achmea judgment into consideration.

\section{Bibliography}

1. Alfons C., Recognition and Enforcement of Annulled Foreign Arbitral Awards, Peter Lang, Frankfurt am Main 2010

2. Bates E., Avoiding Legal Obligations Created by Human Rights Treaties, 'International and Comparative Law Quarterly' 2008, vol. 57, no. 4

3. Dederer H-G., Daniel Wüger, and Thomas Cottier, Genetic Engineering and the World Trade System [in:] Herrmann Ch., Terhechte J. P. (eds.) 'European Yearbook of International Economic Law 2011', Springer, Berlin 2011

4. Dimopolulos A., Achmea: The principle of autonomy and its implications for intra and extra-EU BITs, https://www.ejiltalk.org/achmea-the-principle-ofautonomy-and-its-implications-for-intra-and-extra-eu-bits/\#more-16051

5. Douglas-Scott S., Constitutional Law of the European Union, Pearson Education, Harlow 2002

6. Dörr O., Schmalenbach K. (eds.), Vienna Convention on the Law of Treaties. A Commentary, Springer, Berlin 2018

7. Eckes Ch., Don't Lead with Your Chin! If Member States Continue with the Ratification of CETA, they Violate European Union Law, http:// europeanlawblog.eu/2018/03/13/dont-lead-with-your-chin-if-memberstates-continue-with-the-ratification-of-ceta-they-violate-europeanunion-law/

52 E.g. in 2014, Poland obtained EU authorisation to enter into BIT negotiations with Armenia and Ethiopia (Décision d'exécution de la Commission autorisant la République de Pologne à ouvrir des négociations officielles en vue de la conclusion d'accords bilatéraux d'investissement avec, respectivement, la République d'Arménie et la République d'Éthiopie, C(2014)9139/F1). 
8. Gáspár-Szilágyi S., It Is not Just About Investor-State Arbitration: A Look at Case C-284/16, Achmea BV, http://www.europeanpapers.eu/en/europeanforum/ it-is-not-just-about-investor-state-arbitration-achmea-case

9. Hepburn J., Domestic Law in International Investment Arbitration, Oxford University Press, Oxford 2017

10. Jenks C. W., The Interpretation and Application of Municipal Law by the Permanent Court of International Justice, 'British Yearbook of International Law' 1938, no. 19

11. Kantor M., Valuation for Arbitration: Compensation Standards, Valuation Methods and Expert Evidence, Wolters Kluwer, Alphen aan den Rijn, 2008

12. Klamert M., The Principle of Loyalty in EU Law, Oxford University Press, Oxford 2014

13. Kolb R., The Law of Treaties: An Introduction, Edward Elgar, Cheltencham 2016

14. Kułaga Ł., Traktowanie sprawiedliwe isłuszne a minimalny standard traktowania $w$ międzynarodowym prawie inwestycyjnym, Wydawnictwo UKSW, Warsaw 2016

15. Kułaga Ł., Międzynarodowy arbitraż inwestycyjny z perspektywy zasady rządów prawa [in:] C. Mik (ed.), 'Arbitraż w prawie międzynarodowym', C.H. Beck, Warsaw 2014

16. Kułaga Ł., Unia Europejska a zmiana paradygmatu w międzynarodowym prawie inwestycyjnym, 'Europejski Przegląd Sądowy' 2017, no. 4 (139)

17. Kułaga Ł., $W$ kierunku zmiany paradygmatu międzynarodowych porozumień inwestycyjnych, 'Forum Prawnicze' 2016, no. 5 (37)

18. Kułaga Ł., Ochrona praw człowieka $w$ międzynarodowym arbitrażu inwestycyjnym, 'Forum Prawnicze' 2014, no. 1 (21)

19. Menkes M., Governance gospodarczy - studium prawnomiędzynarodowe, C.H. Beck, Warsaw 2016

20. Mik C., Europejskie prawo wspólnotowe. Zagadnienia teorii i praktyki. Tom 1, C. H. Beck, Warsaw 2000

21. Newcombe A., Paradell L., Law and Practice of Investment Treaties: Standards of Treatment, Wolters Kluwer, Alphen aan den Rijn 2009

22. Niemelä P., Achmea - A Perspective from International (Investment) Law, https://europeanlawblog.eu/2018/03/15/achmea-a-perspective -from-international-investment-law/

23. Pamboukis Ch., The Annuled Arbitral Award. Jurisdictio Facit Arbitrum, 'Yearbook of Private International Law' 2015/2016, vol XVII

24. Paulson J., Denial of Justice in International Law, Cambridge University Press, Cambridge 2005

25. Pauwelyn J., Conflict of Norms in Public International Law, Cambridge University Press, Cambridge 2003 
26. Rogulski P., Rozwiązywanie sporów inwestycyjnych - doświadczenia polskie [in:] Kuźniak B. (ed.), 'Sądy i trybunały oraz pozasądowe sposoby załatwiania sporów międzynarodowych. Perspektywa polska', C. H. Beck, Warsaw 2015

27. Różalska-Kucal A., Intra-EU BITs - are They Really Still Necessary? The Best Award of the Year 2012 and Professor Emmanuel Gaillard Say "Yes", 'Polish Review of International and European Law' 2012, vol. 11, no. 3-4

28. Thym V. D., The CJEU ruling in Achmea: Death Sentence for Autonomous Investment Protection Tribunals, http://eulawanalysis.blogspot. com/2018/03/the-cjeu-ruling-in-achmea-death.html

29. Wagner D., Managing Country Risk: A Practitioner's Guide to Effective CrossBorder Risk Analysis, CRC Press, New York 2012

30. Welsh N., Schneider A., The Thoughtful Integration of Mediation into Bilateral Investment Treaty Arbitration, 'Harvard Negotiation Law Review' 2013, vol. 18

31. Wróbel A., Stosowanie prawa Unii Europejskiej przez sq̨dy. Tom I, Wolters Kluwer, Warsaw 2010

32. Yannaca-Small Y., Interpretation of the Umbrella Clause in Investment Agreements, OECD Working Papers on International Investment 2006/03, OECD Publishing 